\title{
ILCEA
}

Revue de l'Institut des langues et cultures

d'Europe, Amérique, Afrique, Asie et Australie

$18 \mid 2013$

Les frontières dans le monde hispanique

\section{Miradas cruzadas sobre la frontera México- Estados Unidos a través de la narrativa mexicana del nuevo milenio: David Toscana (El ejército iluminado, 2006) y Yuri Herrera (Trabajos del reino, 2004 y Señales que precederán al fin del mundo, 2011)}

Regards croisés sur la frontière entre le Mexique et les États-Unis à travers la littérature mexicaine du nouveau millénaire : David Toscana (El ejército iluminado, 2006) et Yuri Herrera (Trabajos del reino, 2004 et Señales que precederán al fin del mundo, 2011)

Glances across the Border between Mexico and the United States through the Mexican Literature of the New Millennium: David Toscana (El ejército iluminado, 2006) and Yuri Herrera (Trabajos del reino, 2004 and Señales que precederán al fin del mundo, 2011)

\section{Margarita Remón-Raillard}

\section{OpenEdition}

\section{Journals}

Edición electrónica

URL: http://journals.openedition.org/ilcea/2154

DOI: 10.4000/ilcea.2154

ISSN: 2101-0609

\section{Editor}

UGA Éditions/Université Grenoble Alpes

Edición impresa

ISBN: 978-2-84310-251-6

ISSN: $1639-6073$

Referencia electrónica

Margarita Remón-Raillard, « Miradas cruzadas sobre la frontera México-Estados Unidos a través de la narrativa mexicana del nuevo milenio: David Toscana (El ejército iluminado, 2006) y Yuri Herrera ( Trabajos del reino, 2004 y Señales que precederán al fin del mundo, 2011) », ILCEA [En línea], 18 | 2013 Publicado el 11 julio 2013, consultado el 01 mayo 2019. URL : http://journals.openedition.org/ ilcea/2154 ; DOI : 10.4000/ilcea.2154

Este documento fue generado automáticamente el 1 mayo 2019.

(c) ILCEA 
Miradas cruzadas sobre la frontera México-Estados Unidos a través de la narrativa mexicana del nuevo milenio: David Toscana (El ejército iluminado, 2006) y Yuri Herrera ( Trabajos del reino, 2004 y Señales que precederán al fin del mundo, 2011)

Regards croisés sur la frontière entre le Mexique et les États-Unis à travers la littérature mexicaine du nouveau millénaire : David Toscana (El ejército iluminado, 2006) et Yuri Herrera (Trabajos del reino, 2004 et Señales que precederán al fin del mundo, 2011)

Glances across the Border between Mexico and the United States through the Mexican Literature of the New Millennium: David Toscana (El ejército iluminado, 2006) and Yuri Herrera (Trabajos del reino, 2004 and Señales que precederán al fin del mundo, 2011)

Margarita Remón-Raillard

«Nosotros somos los culpables de esta destrucción, los que no hablamos su lengua ni sabemos estar en silencio. Los que no llegamos en barco, los que ensuciamos de polvo sus portales, los que rompemos sus alambradas. Los que venimos a quitarles el trabajo, los que aspiramos a limpiar su mierda, los que anhelamos trabajar a deshoras. Los que llenamos de olor a comida sus calles tan 
limpias, los que trajimos violencia que no conocían, los que transportamos sus remedios, los que merecemos ser amarrados del cuello y de los pies; nosotros, a los que no nos importa morir por ustedes, ¿cómo podía ser de otro modo? Los que quién sabe qué aguardamos. Nosotros los oscuros,

los chaparros, los grasientos, los mustios, los

obesos, los anémicos. Nosotros, los bárbaros.» Yuri HERRERA, Señales que precederán al fin del mundo,

pp. 109-110.

1 Se ha vuelto un tópico decir que la frontera entre México y EEUU es lugar y motivo de reflexión identitaria y de procesos de creación sociocultural, tanto como para un país como para el otro. En efecto, la frontera ha sido recreada en la literatura mexicana y estadounidense. El arte y la cultura en México se han visto marcados por el surgimiento de una serie de metáforas emocionales de la frontera que van desde las imágenes de la herida abierta, la ruptura o la mutilación hasta la de la traición ${ }^{1}$. Según muchos especialistas, esta realidad histórico-geográfica que es la frontera y sus producciones culturales han sido interpretadas a menudo desde "perspectivas homogeneizantes» que redundan en visones reductoras y estereotipadas. Según ellos, figuras de la talla de Vasconcelos, Rulfo, Paz o Fuentes han contribuido a reproducir visiones estereotipadas de la frontera ${ }^{2}$.

Por otro lado, el deseo de autognosis es una constante a lo largo de la historia mexicana y cristaliza con la revolución. En efecto, definir y delimitar lo mexicano se convierte en el lema de toda una generación de intelectuales durante el periodo posrevolucionario. Ya sea de forma dogmática, ya sea desde posiciones disidentes, México y «lo mexicano» se erigen en una especie de paradigma de las letras, las artes y la filosofía. Desde posturas desencantadas, como la novela de la revolución mexicana, hasta la explotación por la literatura fantástica del tema del pasado prehispánico reprimido, pasando por otros tipos de manifestaciones artísticas de la «cortina de nopal», se trata de un movimiento de inmersión para frotarse con una problemática identitaria que fue, y sigue siendo, sumamente fructífera a nivel de las artes en general, a pesar de sus deficiencias y límites.

3 El auge y carácter prolífico de una narrativa cuya temática se centra en la frontera entre México y Estados Unidos no deja de inscribirse en esta trayectoria de las letras mexicanas. El escritor Juan Villoro señala en este sentido que «no es extraño que en la narrativa mexicana de fin de siglo se privilegie el extremo norte del territorio para discutir tanto de la influencia de una cultura que siempre parece llegar tarde como la construcción de una nueva identidad $»^{3}$. La frontera es el nuevo sitio de construcción de un imaginario identitario. Sin embargo, por su carácter multifacético, maleable y mutante, la frontera sugiere otras formas de plantear la identidad mexicana, dejando atrás las monolíticas formas del pasado:

En la literatura mexicana contemporánea predomina una concepción pulverizada, dispersa, múltiple, híbrida, de la identidad. Resulta ocioso buscar el rostro primigenio e inmutable. Al contrario, las diversas máscaras, de Tenochtitlán a Chiapas, de las caretas emplumadas de los Caballeros de Águila al pasamontañas del subcomandante Marcos, son identidad ${ }^{4}$.

4 Hay que señalar que la frontera cristaliza igualmente la manera en que desde fuera se percibe México y lo mexicano. Se trata del mismo prisma reductor con que se ha 
percibido lo latinoamericano en general y lo mexicano en particular, sólo que la focalización se ha restringido aún más. La narrativa mexicana (y latinoamericana) no ha dejado de realizar una fuerte crítica no solamente del colonialismo cultural y del eurocentrismo sino también de la forma en que el mexicano de «adentro» se percibe a sí mismo. Así, en muchas obras de ficción la mirada cumple el objetivo de discernir los contornos de un objeto particular: México. Varios puntos de vista cohabitan dando como resultado una visión caleidoscópica de México «donde los cristales rotos cambian de color tanto como los camaleones observados. El cruce de miradas va de lo desenfocado a lo alucinatorio. Es lógico que así sea. No hay miradas puras ni realidades intactas» ${ }^{5}$.

5 Así pues la llamada «identidad» no sale ilesa de ese cruce de miradas, de manera que, según Villoro, «la palabra "identidad" ya sólo denota una máscara, [...] $»^{6}$. No se trata entonces de una noción monolítica sino moldeada constantemente por el juego de las intersubjetividades. Según Villoro, el eurocentrismo realiza una distorsión al ensalzar la alteridad a ultranza en aras del respeto a la diversidad, pero teniendo como base toda una «retórica de la culpa»?. La crítica que hace Villoro de la visión empecinada europea se basa en gran medida en la lectura surrealista de América Latina que se ha hecho desde Europa, que busca satisfacer lo que él llama una «curiosa necesidad del imaginario europeo: la utopía del retraso» ${ }^{8}$.

6 La frontera ha brindado una nueva juventud a esta visión reductora convirtiéndose en sitio privilegiado en el que continúa el mismo proceso de reflexión y cuestionamiento identitarios. Ante la pléyade de escritores mexicanos (y de otros orígenes) que producen obras en torno a la frontera, hemos elegido detenernos en dos casos que nos parecen representativos de las narrativas de esta primera década del siglo xxi: David Toscana ( $E l$ ejército iluminado, 2006) y Yuri Herrera (Trabajos del reino, 2004, y Señales que precederán al fin del mundo, 2010). En estas novelas se hace operativa la problemática de la mirada, o más bien del cruce de miradas, que se focaliza en este espacio geográfico y cultural que es la frontera entre México y Estados Unidos. La resultante es una visión que busca rectificar, a través de recursos múltiples, viejos agravios históricos, ciertos estereotipos o, sencillamente, sugerir que la realidad de la frontera permanece inasible, ambigua o equívoca. De tal forma que hasta el mismo concepto de frontera oscila entre ruptura y continuidad, en el sentido amplio de los términos: entre categorías conceptuales u ontológicas hasta categorías socioculturales ancladas en un referente preciso.

7 Si bien el auge del tema de la frontera se inscribe en el marco de la problemática de la producción cultural en el norte de México y de la hegemonía del centro en materia de edición y promoción, por razones evidentes de espacio este trabajo optará por una óptica esencialmente textualista. Esto conlleva igualmente el hecho de que no consideremos determinante, aunque sí significativo, el impacto en los textos de los orígenes de los autores estudiados. Es decir que no entraremos en la polémica en torno a saber si se trata de escritores «de la frontera» o «sobre la frontera», etc., lo cual atañe más bien al ámbito de la sociología de la literatura; aunque sí volveremos sobre este punto a manera de conclusión.

8 El escritor de Monterrey, David Toscana, nos ofrece una narración desopilante en torno a la pérdida de la mitad del territorio mexicano y las consecuencias que esto engendró a todo nivel. Ignacio Matus es un personaje al margen de la Historia. Sin embargo, hará todo lo necesario no sólo para que ésta lo tome en cuenta sino también para rectificarla. Su primer intento tiene lugar en 1924 cuando organiza, con la ayuda de un par compañeros de dominó y borracheras, un maratón paralelo al que tiene lugar en París 
durante las olimpiadas de ese año. Matus se cronometra para salir al mismo tiempo que sus contrincantes al otro lado del Atlántico y su itinerario sigue las vías del tren que llevan a la frontera con los EEUU. Cuarenta y dos años más tarde Matus enseña historia en la secundaria, pero la manera poco ortodoxa de abordar algunos capítulos, esencialmente la batalla de El Álamo, le cuesta su puesto. Es entonces cuando decide organizar una expedición de recuperación de lo que le pertenece a México. Para ello, Matus recurre primeramente al Gordo Comodoro, un chico visiblemente minusválido y huérfano, del cual Matus se ocupa. Comodoro se encarga de reclutar, entre sus compañeros de la escuela especializada a la que asiste, a un contingente de valientes: el ejército de los iluminados. Los logros de esta expedición alucinante no son los esperados y Matus decide, en vísperas de las olimpiadas que se celebrarán en México en 1968, realizar otro maratón paralelo, que le costará la vida.

La novela pone de manifiesto que existen otras formas de leer la Historia así como su carácter contingente, es decir la posibilidad de modificarla o rectificarla gracias al poder de la ficción. Hay que señalar que esta "rehistorización de la historia de México»" ${ }^{9}$ es frecuente en la obra de Toscana. La focalización del relato permite este juego de rectificación de la Historia. En efecto, los hechos los percibimos según el punto de vista de Matus y sus iluminados, pero el conjunto se ve pautado con las intervenciones de una voz externa que nos devuelve a la «realidad» o, más bien, a la lectura oficial de la Historia. La llamada realidad histórica se ve cuestionada por otra visión, novelesca, delirante, conmovedora, pero no por ello falsa. Se establece un fuerte contraste entre esta visión (la de los excluidos de la historia) y la visión «centralista y nacionalista de la historia» ${ }^{10}$. El desfase así creado produce toda una poética del desencanto, no desprovista de ironía y humor negro. Las fechas a la que remite el texto adquieren un valor particular: 1924 es el año de la llegada al poder de Plutarco Elías Calles y 1968 el año de la masacre de Tlatelolco, dos fechas de suma importancia en la creación, asentamiento y decadencia del aparato hegemónico estatal mexicano, basado en la supremacía del partido único.

Por otro lado, la forma en la que el texto aborda la temática histórica da paso a una serie de metáforas emocionales, ya tradicionales, en torno a la frontera, mencionadas más arriba. Cuando un especialista como José Valenzuela Arce afirma que «ruptura y pérdida son los elementos que marcaron la percepción desde México de la frontera» ${ }^{11}, \mathrm{o}$ «la patria se convirtió en metáfora dolorosa que no lograba resarcir sus heridas» ${ }^{12}$, podemos afirmar que la novela ilustra elocuentemente una necesidad de cicatrización aún presente en el imaginario mexicano.

11 La primera ocasión que se le presenta a Matus para resarcir esa herida la encuentra en la prueba de maratón de las olimpiadas parisinas de 1924. El maratón aparece como una metáfora de lucha con armas iguales por medio de la cual Matus puede encontrar la revancha con respecto a EEUU ya que, de hecho, su principal contrincante, y favorito de la prueba, es Clarence DeMar, representante de esa nación. Matus corre siguiendo las vías del tren que van a Saltillo y a Piedras Negras (p. 79) ${ }^{13}$ pero mentalmente reproduce un París imaginado y visualiza a sus contrincantes:

Matus piensa acecharlo [a Clarence DeMar], para al final rebasarlo con sus zancadas rápidas. Te espero en la meta, gringuito, le dirá, y echará el remanente de sus fuerzas para desencantar a las parisinas, porque la corona de olivo y la medalla de oro serán para un apestoso mexicano sin un peso en el bolsillo, y a ver quién diablos viene a abrazarme, a besarme, a mojar su vestido dominical con mi sudor, a posar en la fotografía, a revolcarse en la cama con ese salvaje antillano o centroamericano o caribeño o dónde diablos queda México. (p. 50) 


\section{mundo recreado no deja de expresar un fuerte sentimiento de inferioridad con respecto a} la cultura occidental hegemónica. El pasaje nos envía a la teoría de Samuel Ramos ${ }^{14}$ según la cual la imitación europea del siglo xix conlleva la autodenigración y el desdoblamiento del mexicano en dos planos, uno real y uno ficticio. Como se sabe, Octavio Paz matizará la existencia de este sentimiento de inferioridad del mexicano afirmando que se trata más bien de un sentimiento de soledad, pero asentará la visión del mexicano como ser que vive en el simulacro o usando diversos tipos de máscaras. Sin embargo, las palabras de Matus no dejan de recordar cuán cierto es también el desprecio o paternalismo con el que Europa y EEUU perciben a los países llamados tercermundistas. Una primera revancha, e inversión de tópicos, se encuentra en el hecho de que el maratón de París sale con retraso, lo cual no le facilita a Matus el conteo cronometrado que tenía planeado pero, como le dice su amigo, «lo que importa es que tú sí fuiste puntual [...]» (p. 108).

Matus logra un tiempo de 2:47:50 mientras que DeMar hace 2:48:14, es decir que el mexicano rebasa al norteamericano (que gana la medalla de bronce) por 24 segundos. Matus le escribe a DeMar reclamándole la medalla: «El hecho de que mi gobierno no tuviera interés en pagar mi boleto a París no hace que yo desmerezca el reconocimiento que me corresponde, pues yo lo vencí a usted en velocidad, aunque usted me haya vencido en dólares» (p.119). El texto plantea el potencial que posee el deporte para rectificar las injusticias de la historia, poniendo en escena esta modalidad eterna y recurrente que pueden adoptar las competencias internacionales cuando los países saldan cuentas en otro terreno: el deporte tiene un gran potencial novelesco. DeMar terminará enviándole, de forma póstuma y 42 años más tarde, la medalla a Matus cuando éste último acaba de sufrir otra derrota con sus iluminados.

readidad, al acercarse los juegos olimpicos del 68, Matus vuelve a sentir ese llamado a la rectificación de la historia a través del deporte. No sólo la fecha es significativa sino que Matus la percibe como una repetición de viejas afrentas:

Le molesta pensar que en pocos días comienzan las olimpiadas y, como de costumbre, los gringos van a arrollar a sus rivales y de nuevo harán ondear su bandera en la capital mexicana, igual que lo hizo su ejército en 1848, y entonarán el himno nacional una y otra vez y obligarán a la gente a ponerse de pie y saludar, y los demás países habrán de conformarse con sitios del segundo para abajo, y México más en el fondo, allá donde se reparten las migajas. (pp. 35-36)

El uso del polisíndeton traduce el hastío del personaje ante estas humillaciones que desafían el tiempo al hacerse eternas. Matus busca romper ese eterno ciclo en el que su país se debe satisfacer de migajas y renunciar a la mejor porción, léase esa parte del territorio perdida tras 1848. Al no tener la vitalidad que tenía en 1924, Matus trata de reparar esa afrenta a través del magisterio. Su visión de cómo debieron ser la cosas la expresa a través del mapa que utiliza para dar clases de historia:

La pared del fondo [de su aula] exhibe un mapa antiguo en el cual aún puede verse un territorio arriba del río Bravo como parte de la república mexicana. En él basa sus clases más apasionadas de historia; golpea con el índice una serie de ciudades: San Antonio, Los Ángeles, San Francisco, Santa Bárbara, y pregunta a sus alumnos ¿por qué creen que tienen nombres en español? [...]. Cada año el director le riñe por su forma delirante de tratar el tema, porque aplaude el modo en que el general Santa Anna acaba con todos los miserables de El Álamo, a unos en la batalla, al resto pasándolos a cuchillo, mueran infelices, porque la rendición no es motivo de indultar a los rufianes que nos roban la patria; y narra gozoso la manera en que los

ILCEA, 18 | 2013 
mexicanos apilan los cadáveres gringos, les amontonan leña y prenden una enorme fogata donde los cabellos son lo primero en consumirse; [...] (pp. 17-19)

He aquí el ideal histórico-geográfico que Matus buscará concretizar con su ejército iluminado. No es casual la referencia al mapa como representación del poder a través del asentamiento de un territorio que es garante de éste. El personaje se aferra a la representación cartográfica de una situación pasada en la que México no se satisfacía con migajas. Por otro lado, en lo que se refiere a la historia, Matus se centra en un episodio algo oculto de la historia mexicana, y no de los más gloriosos, y se nos aparecerá como una nuevo Santa Anna que, en esta nueva vida, no entierra su pierna, sino que las usa para correr, cual Forrest Gump regiomontano. Su lectura de este episodio histórico no es compartida ni por sus alumnos ni, peor aún, por el director de la escuela:

Sabe que esa mañana tendrá problemas porque el viernes llamó cobardes a sus alumnos, vendepatrias; los jóvenes de hoy nacen derrotados, les dijo, con calzones en el suelo, incapaces de tomar un rifle si no es de juguete; y uno de ellos, un tal Arechavaleta, se puso de pie y dijo que en Estados Unidos las calles no tenían baches y la ropa era mejor y más barata y los aparatos eléctricos sí funcionaban y el gobierno no robaba y bien hubieran hecho en poner la frontera no en río Bravo, sino más abajo, al sur de Monterrey, y así seríamos gringos y los sueldos se pagarían en dólares y... No continuó porque Matus lo tomó de una oreja y lo echó del salón. (pp. 17-18)

17 Nuevamente el polisíndeton pone en evidencia una estructura argumentativa, en este caso más densa: una lista interminable (como lo sugieren los puntos suspensivos) de aspectos positivos e irrebatibles que muestran que la gran ventaja de EEUU es que el Estado funciona y cumple. Arechavaleta representa el punto de vista utilitarista y pragmático, en oposición al nacionalismo teñido de locura representado por Matus. El director de la escuela es, como es de esperarse, partidario de una versión oficial que llama a la resignación y a la conciliación. Así como México debe aceptar su derrota, Matus debe aceptar la suya propia:

No había necesidad [le dice el director] de hablarles sobre esa guerra ni hacer pasar a los Estados Unidos como nuestro enemigo, bastaba con relatarles que Santa Anna les vendió el territorio; es más sano odiar a un presidente muerto que a nuestros vecinos del norte. En un arranque de dignidad Matus levanta la voz. Creo que mi deber es informar a los alumnos... Sin embargo el director la levanta aún más. La escuela es un lugar de formación, no de información, así es que firme de una vez y acepte, igual que México, que perdió la guerra. (p. 25)

La cadena argumentativa de uno es cortada por el otro: el alumno corregido por el profesor y éste por el director, es decir la institución y es esta visión la que se impone. La visión del director de la pérdida del territorio como mal necesario hace eco a la ya asentada de Justo Sierra quien afirmó que México construye su identidad nacional dolorosamente por supresión. Para Sierra es paradójicamente gracias a esta pérdida, inevitable, que se garantiza la consolidación nacional de México ${ }^{15}$. Matus, al no conformarse con esa visión de la historia y con esa concepción de la enseñaza, busca oídos anuentes para recibir su versión de la «información» y mentes moldeables a la «formación» que él quiere dar. Es así cómo se lanza en la empresa de crear un ejército para cruzar la frontera y recuperar Texas. Comodoro es el encargado del reclutamiento. Es así como se crea el ejército de los iluminados compuesto por él mismo, Azucena, Ubaldo, un chico al que llaman «El Milagro» (porque fue el único de su familia que sobrevivió a un accidente de coche que le causó estragos en el cerebro) y Cerillo, que parece sufrir de autismo o alguna patología semejante. 
19 A través del desfase creado por la focalización del relato surge el humor tragicómico: el lector es espectador de una aventura rocambolesca que sabe que no puede terminar bien pero, al mismo tiempo, vive los eventos a través de los ojos de los iluminados, participando en esta versión encantada de la historia. Matus escucha esa noche una discusión de Comodoro en el teléfono:

De acuerdo, tiene que ser lo antes posible si queremos el elemento sorpresa a nuestro favor; no, yo tampoco conozco el camino, pero seguramente vendrá en un mapa; sí, ese territorio es nuestro, nos pertenece todo lo que se llama Texas, lo sé de buena fuente. La conversación lleva un par de minutos cuando Comodoro se golpea la frente con la palma de la mano. Sería nuestra perdición, dice y afloja el cuerpo, se enjuga el sudor del bozo, en ese caso nuestros planes se irían al diablo. Yo no sé de esos asuntos, pero aquí tengo a Matus, voy a consultarlo con él. Comodoro tapa la bocina con la mano y se dirige a Matus con voz temblorosa. ¿Es cierto que para ir a Texas hace falta pasaporte? (pp. 39-40)

El texto juega con la ambigüedad al no explicitar ni la edad de los iluminados ni sus patologías. Sólo en un episodio de la aventura se hace mención de este aspecto. Ya han emprendido la expedición y Matus decide que sus soldados deben iniciarse al amor antes de emprender la guerra. Los lleva a un prostíbulo, dejando a Azucena encargada de custodiar la carreta y el burro que los empuja: “¿Qué edad tienen?, pregunta ella [una amiga de Matus] mientras los escruta con los ojos. Yo qué sé, con esta gente es imposible calcular, pero cualquiera que esté listo para morir, debe también estarlo para amar" (p. 86). Con la réplica de Matus ambas preguntas quedan sin respuesta.

Uno de los momentos más conmovedores en cuanto al desfase de perspectivas lo encontramos en la descripción del contenido de las mochilas de los iluminados. Se trata de un paréntesis descriptivo (pp. 73-77) asumido por esa voz externa que es la que permite al lector reubicarse en otro plano que no es el del encanto iluminado. Así, algunos llevan talco para bebés, otros sus lápices de colores, la mejor equipada para la guerra, Azucena, lleva un rollo de esparadrapo en su mochila rosa decorada con la imagen de una patinadora.

Los iluminados están preparados para perder la vida en la batalla, así los ha aleccionado Matus. Es por ello que decide realizar un simulacro de misa mortuoria por parte de un cura que, por lo visto, se presta al juego. Nuevamente surge con humor el desfase:

Señor, dice el cura desde el púlpito, fuiste avaro en gracias con estos muchachos, ahora te toca ser dadivoso con sus ánimas; recíbelas lo mismo puras que mancilladas, victoriosas que vencidas, porque es gente que en todo momento estuvo dispuesta a ofrecer el mayor de los sacrificios: la vida por la patria que se volvió la vida por la nada porque su valor fue inútil contra la certera artillería del enemigo, mitad ateo, mitad protestante, si bien ambas mitades son lo mismo; porque la espada flamígera de la fe de poco sirve con una bala en el occipucio y a estos infelices no les detuviste el sol ni les abriste las aguas del río Bravo ni les derribaste El Álamo a trompetazos ni nada de esas artimañas con las que solías ayudar a tus prosélitos de otros tiempos. Recibe, señor, a estas cinco almas por la puerta principal porque lo tienen bien ganado. Aleluya, grita Comodoro y gira para acomodarse bocabajo porque el suelo es irregular y le cala en la espalda. (pp. 98-99)

El desfase creado es tanto más evidente cuanto que este episodio se inicia in medias res, haciendo mención de los «cuerpos» de los iluminados extendidos en el suelo de la Iglesia, antes de pasar al sermón del cura. En efecto, la novela no se organiza en capítulos numerados sino a través de secuencias narrativas separadas por un espacio tipográfico. La secuencia anterior termina evocando la posibilidad que acecha a los iluminados de 
perecer en la acción, con lo cual el siguiente fragmento toma desprevenido al lector que puede optar momentáneamente por la elipsis. La intervención de Comodoro, con una sola palabra, devuelve al lector al delirio narrativo en el que sustenta la novela. En la prédica del cura se mezclan las referencias míticas, bíblicas e históricas. Aparece, con mucha ironía, la idea de que ese Dios al que ruega por las almas de los chicos no estuvo nunca, cualquiera que sea el ámbito discursivo, del lado de México, con lo cual tenemos otro llamado a la rectificación de la historia.

Finalmente, Matus deja solos a los iluminados para ir en busca de víveres, les dice que si no llega en tres horas querrá decir que ha sido atrapado por el enemigo y que deberán seguir sin él. Al no saber cuantificar el tiempo, los chicos deciden que Matus no regresará, continúan la ruta sin él y llegan a lo que creen ser el río Bravo. Todos tienen en mente una lección de zoología de la maestra y atraviesan un imaginario río Bravo poblado por pirañas. Comodoro cruza primero y solo, en un momento de pánico, recordando que tras la lección de la maestra sus amigos habían evocado la posibilidad, si alguna vez se encontraban en el trance de atravesar un río, de empalarlo y utilizarlo como señuelo. Comodoro duda que sus amigos sean tan desmemoriados y, de hecho, no lo son, atravesando apresuradamente el río. Cuando el resto de la tropa se lanza a la travesía con carreta, burro y Cerillo dormido, Comodoro piensa que la corriente y las pirañas acabarán con sus amigos (y con la misión). Se le ocurre utilizar un sobre de gelatina verde para solidificar el río y para que sus amigos puedan caminar sobre él, como Jesús. Lo efímero del color verde tiñendo algunos centímetros cúbicos de agua es una de esas visiones, múltiples en la novela, que crean un efecto tragicómico que, en este caso, desmitifica totalmente lo que tendría que ser el momento clave de la novela (y que lo es en muchas producciones artísticas en torno al tema: literatura, cine, etc.): el cruce de la frontera. En su lugar, la escena ejemplifica toda una estética del disparate que es, a nuestro parecer, el mejor logro de la novela.

Sin embargo, tanto los iluminados como Matus persisten en su visión mítica o encantada. Matus finalmente alcanza a sus soldados y los encuentra en un rancho que habían vandalizado, convencidos de hallarse ya en territorio enemigo. Incluso llegan a disparar (pues las armas que llevan sí son de verdad) a un par de hombres que pasaban, sin percatarse de que el color moreno de sus pieles, sus bigotes, sombreros o risotadas, mostraban que se trataba de paisanos. Uno de los dos resulta muerto; el otro va en busca del ejército que llega rápidamente para apresar a los criminales. Es así como se da la verdadera batalla entre los iluminados y los que ellos creen ser los gringos. El Gordo Comodoro pierde la vida arma en mano. El resto es llevado al cuartel de la policía en un camión del cual se cae Cerillo sin que nadie se percate de ello y luego lo dan por muerto.

La muerte de Comodoro, y de Cerillo, le brinda a Matus lo que necesitaba para proyectarse en un futuro en el que la historia por fin se rectifica y da su lugar a los que lo merecen, creando toda una mitología en torno a estos nuevos «Niños Héroes»:

Dígame, profesor, ¿quién fue el gordo Comodoro? ¿Quiénes fueron Cerillo, Ubaldo y ese individuo llamado el Milagro? Matus se imagina de nuevo en la escuela, ahora con alumnos receptivos que lo admiran sin reparos, sin llevar quejas a sus madres. Y dedica especial atención a instruirlos sobre el sacrificio del gordo Comodoro, quien no cesó de disparar hasta que el rifle se destrozó en sus manos; y elabora la leyenda de Cerillo, y dice que ahí donde cayó ahora se levanta un nogal macizo como la piedra [...] (pp. 197-198)

27 Matus crea la réplica de la fundación de Tenochtitlán. Este nuevo sitio fundacional (o nuevo Aztlán, si se quiere), según los cálculos de Matus, se encuentra a unos 
42 kilómetros de la verdadera frontera. Para compensar esa misma distancia que lo separó del triunfo real, intentará correr un último maratón mortal (p. 222). El texto juega con las cifras buscando, a través de ellas, subrayar la contingencia de la realidad y la posibilidad (o imposibilidad) de invertirla o trastocarla. En efecto, 42 no es sólo la distancia reglamentaria de la prueba olímpica (y la distancia entre Atenas y Maratón) sino también la misma cifra que encontraba «El Milagro» cuando se empecinaba en recuperar sus facultades intentando multiplicar de forma obsesiva 11x8. Esa otra lógica, otra forma de calcular el mundo, se salda por el desencanto, la imposición de la norma sobre la diferencia, la ausencia de milagro. Los 24 segundos que le dieron a Matus su victoria imaginada sobre EEUU, en 1924, jamás se van a invertir, 42 años más tarde, para permitirle alcanzar el triunfo real y alcanzar la frontera.

El texto declina el desencanto en varios episodios que cierran la novela. Primeramente, en el presente de la narración la voz externa rectifica la visión de los iluminados al mencionar el «archivo Policía Judicial de Nuevo León», en el cual aparece una denuncia «fechada del 15 de octubre de 1968» sobre un rancho vandalizado por unos desconocidos: «El documento, sin embargo, es útil para ubicar a los iluminados, quienes aún se hallaban a unos cuarenta kilómetros de la frontera. De ser así, el río que atravesaron debió ser el arroyo Camarón, que hoy día está seco la mayor parte del año» (p. 197). La voz externa echa por tierra la versión heroica de una travesía por un caudaloso río infestado de pirañas: cada término empleado funciona como una hipérbole al revés; lo novelesco cede ante la historia documentada.

Así como la travesía del río Bravo es objeto de encanto y desencanto, algo similar sucede con el trato del máximo símbolo de la nación: la bandera. Así, antes de empezar la expedición, Matus había explicado a sus soldados: «nuestro abanderado deberá cargar igualmente con fusil, capa, puñal y puños, de modo que habrá de llevar la bandera en la espalda hecha capa de superhéroe» (p.117). Luego, Ubaldo confeccionará una bandera para marcar la posesión del rancho vandalizado: «Ahí donde debía estar el águila devorando una serpiente, hay un pollo con una corona, comiéndose una lombriz» (p. 150). Nuevamente el archivo policial nos proporciona la versión desangelada: «asimismo encontró [el dueño del rancho vandalizado] en una pared interior el dibujo de una bandera mexicana adulterada con un pollo imperial, en vez de águila, lo cual, tiene él entendido, es delito federal» (p. 196).

30 Así pues, Matus y los iluminados deben rendir cuentas a la justicia y a la ley federal por esta ridiculización del poder republicano, del estado democrático y de toda una mitología nacional, mientras que Arechavaleta, el vendepatrias, se gana una medalla de oro por recitar con excelencia la Constitución y en particular el artículo 3, el que rige la educación (pp. 223-234). El reconocimiento pertenece a los que entren en el molde y respeten el orden establecido. En este sentido es relevante el pasaje en el que se hace referencia a lo que sucede en México DF en el preciso momento en que la policía interroga a Matus:

Le tengo una buena noticia, dice, lo voy a poner en libertad. Tal parece que eligió el buen momento para su aventura, porque con lo que ocurrió en la Ciudad de México lo que menos queremos es que el ejército siga llamando la atención. No somos perseguidores de gente con ideales, como usted y sus muchachos, sólo tratamos de mantener el orden. (p. 192)

31 La evidente referencia a la masacre de Tlatelolco pone de relieve lo incuestionable del poder hegemónico y al mismo tiempo denuncia que en materia de simulacro y lectura tergiversada de los hechos, éste es más que experto en la materia. 

convirtiéndose en los olvidados de la historia, Matus se lanza a otro maratón. Cae desplomado pocos metros antes de llegar a la meta que se había puesto y un tren lo destroza. Sus compañeros colocan a sus restos la medalla de bronce que Clarence DeMar finalmente le hizo llegar con su viuda. El último párrafo de la novela nos muestra a Matus como el iluminado más que es:

[...] se escuchaba la risa del inmortal corredor de Monterrey, la carcajada del tal Ignacio Matus, que elevaba los brazos y mostraba los puños y cargaba su fusil y comandaba sus tropas hacia esa meta de bandera blanca y águila muerta, hacia esa frontera inalcanzable, absurda y eterna como el río Bravo. (p. 233)

La imagen binaria de la «bandera blanca» y el «águila muerta» recalca que la meta o el objetivo no es más que la rendición y la pérdida del poder, ambas plasmadas en la frontera. Con respecto a un texto anterior (Historias del Lontananza), Toscana afirma que recurrió al término «fracaso» como base operativa de la ficción, definiéndolo como «la incapacidad de que el ser humano tenga la misma dimensión que sus sueños» ${ }^{16}$. Si en el caso de ese texto, el referente histórico en el que se sustenta el fracaso fue el llamado «error de diciembre» de $1994^{17}$, en el caso de El ejército iluminado se trata no solamente del fracaso de 1848 sino también del de 1968; éste último puede ser catalogado como el gran fracaso de la revolución mexicana. En la novela, ambos fracasos encuentran su sitio en la frontera. Sin embargo, no todo es pérdida puesto que la potencialidad creativa del fracaso cristaliza a través de la narrativa. Volviendo al último fragmento citado, lo absurdo y lo eterno pueden ser considerados ingredientes fundamentales de lo imaginario. Si además los acompañan la risa y la carcajada, es decir la capacidad de burlarse de su propio fracaso, la batalla de Matus y los iluminados no hay que darla por perdida: es esta la gran victoria de El ejército iluminado.

Si la novela de Toscana apuesta al realismo del referente pero al delirio y disparate en cuanto a lo narrado, una lógica inversa se opera en las dos novelas de Yuri Herrera. En estas, el referente aparece o no nombrado o sugerido, dándole a la problemática de la frontera un carácter universal. Sin embargo, el mundo narrado es crudamente real, con pocos artificios, pero representado de forma sumamente poética.

El protagonista de Trabajos del reino ${ }^{18}$ es un cantante de corridos, Lobo, que se ve obnubilado por lo fausto de la vida de un rey de la droga. Este último lo emplea como artista de su corte para que componga corridos en su honor. Al ser designado como tal por el Rey, Lobo pierde su identidad y se convierte en el Artista a lo largo de todo el relato; los otros personajes tienen el nombre de su función (el Joyero, el Gerente, el Heredero, la Bruja...). Al carecer el texto de toda referencia explícita a la frontera o al narcotráfico, Yuri Herrera opta por la alegoría narrativa no sólo por razones de seguridad en lo que atañe a su persona, sino para darle a su obra una apertura universal. En efecto, más allá del referente omitido, el texto nos proporciona una reflexión universal sobre la relación entre arte y poder. Asistimos al proceso de aprendizaje de Lobo, cuya visión se va abriendo conforme van pasando las páginas de la novela para culminar con una revelación en torno a su papel como artista y a la autonomía del arte. Nunca se menciona el término frontera pero el texto proporciona suficientes elementos para discernir los contornos de ese espacio preciso que aparece como emblema de mutación, excentricidad, corrupción y que a su vez cuenta con sus propias fronteras internas. Esta multiplicidad de la frontera nos llega a través de la mirada del Artista y esencialmente en su forma de percibir el espacio fronterizo. Yuri Herrera, a diferencia de su siguiente novela Señales que 
precederán al fin del mundo, no hace énfasis en esta novela en el cruce sino en los que se quedan de «este lado», es decir en el lado mexicano. Denuncia una realidad sórdida, violenta, de la cual las principales víctimas son los más débiles y desfavorecidos: los pobres, los niños y las mujeres. Nos centraremos en el manejo que hace el texto de los elementos espaciales que dibujan un cuadro de la frontera. La novela explora otras temáticas, esencialmente la relación entre el arte y el poder o el funcionamiento de la narcocultura, que serán desarrolladas en otro trabajo.

Una de las primeras descripciones de la frontera se centra en la infancia del personaje y en el aprendizaje de la vida que éste tiene que adquirir para poder vérselas con la realidad de esa zona inhóspita. Sus padres lo abandonan para irse al «otro lado» dejándole como único legado un acordeón para sobrevivir:

La calle era un territorio hostil, un forcejeo sordo cuyas reglas no comprendía; lo soportó a fuerza de repetir estribillos dulces en su cabeza [...]. Un día su padre le puso el acordeón en las manos. [...]. - Y abrácelo bien -le dijo-, que este es su pan. Al día siguiente se fue al otro lado. Esperaron sin fruto. Después, su madre cruzó y ni promesas de vuelta le hizo. Le dejaron el acordeón para que se metiera en las cantinas, y en ellas supo que los boleros admiten cara suavecita pero que los corridos reclaman bragarse y figurar la historia mientras se la canta. También aprendió las siguientes verdades: Estar aquí es cosa de tiempo y desgracias. Hay un Dios que dice Aguántese, las cosas son como son. Y, quizá, la más importante: Apártate del hombre que está a punto de vomitar. (pp. 15-16)

La supervivencia de Lobo depende del arte como refugio, de la resignación inculcada a través de la religión y de un mínimo de sentido de la oportunidad para no verse salpicado por la inmundicia ambiental. Es decir que el personaje no tiene conciencia de que su arte puede servir para subvertir ese orden que él no comprende y que, por consiguiente, no puede cuestionar. A lo sumo, el corrido (género musical por el cual optará) requiere «figurar la historia», es decir ser copia fiel o testimonio de la vida de sus protagonistas. Cuando descubre un submundo de la frontera en el palacio del rey, cree que ese mundo y su soberano son una rectificación del mundo torcido que los contiene. Los corridos de Lobo irán en ese sentido, con lo cual la «figuración de la historia» será una puesta en escena de una inversión de valores en la que se asienta el mundo del rey. Lobo termina cantando la alabanza de un mundo de anomia y tendrá que llevar a cabo un proceso de reajuste de valores que le permita ver al rey, y a su corte, como lo que son.

El proceso de aprendizaje de Lobo se ve así pautado por otras visiones que van dejando poco a poco de ser borrosas o distorsionadas. Así, en un primer momento se ve encandilado por este rey cubierto de joyas, su entorno y el lujo que ostenta en un palacio «sostenido en columnas, con estatuas y pinturas en cada habitación, sofás cubiertos de pieles, picaportes dorados, un techo que no podía rozarse [...]» (p. 19). Seguidamente, el personaje percibe otro aspecto de la vida del palacio en el que se halla condensado otro aspecto de la frontera y que es precisamente su gran paradoja: la ruptura de las fronteras. En efecto, una de las primeras descripciones que nos proporciona el texto es la de un sitio en el que la globalización ha hecho su trabajo de zapa de forma precisa y metódica:

Gente de todas partes, de cada lugar del mundo conocido, gente de más allá del desierto. Había, verdad de Dios, hasta algunos que habían visto el mar. Y mujeres que andaban como leopardos, hombres de guerra gigantescos y condecorados de cicatrices en el rostro, había indios y negros, hasta un enano vio. Escuchó de cordilleras, de selvas, de golfos, de montañas, en sonsonetes que nunca había oído; yes como shes, palabras sin eses, y unos que subían y bajaban el tono como si 
viajaran en cada oración, a las claras se notaba que no eran de tierra pareja.

(pp. 19-20) exaltan las hazañas del rey y de otros miembros de la corte. Entre estos cabe destacar los corridos que realiza para dos personajes que aportan otra visión de la frontera: el Gringo y el Pocho. Se trata, en lo que concierne al primero, de aquella imagen vehiculada desde los Estados Unidos. Una serie de consabidos estereotipos en torno al mal más allá de la frontera: la leyenda negra de las ciudades fronterizas con su cortejo de males, drogas, violencia, prostitución y narcotráfico:

Compuso un corrido para el gringo de planta, diestro para idear pasajes de mercancía. Este se había pegado a un hatajo de muchachitos ansiosos de mareo que cada viernes cruzaban a desmayarse de este lado del muro. [...] El más desmedido era un pecoso hijo de cónsul a quien el Gringo devolvía a casa con amor de padre y los asientos hartos de yerba buena. (p. 33)

El texto aborda con cinismo el hecho de que la sordidez de la frontera es alimentada por la falsa inocencia infantil que crea la demanda del lado de «allá» de ese muro. Por otro lado, se hace referencia a la gran figura de la traición y entreguismo, desde el punto de vista mexicano, encarnada por el pocho, aquel que sucumbió a los creadores de la «herida abierta» tras la pérdida de la mitad del territorio ${ }^{20}$ :

Le compuso el suyo al Pocho, quien, casi a a manera de apellido, repetía Yo no crucé la línea, la línea me cruzó. El Pocho había sido agente de allá, hasta que en una encrucijada la justicia lo iluminó: tres de los que eran suyos tenían rodeado al Rey, que ya se disponía a bien morir antes de que lo agarraran, y de pronto lo asaltó un soplo que le decía ¿Y tú por qué has de estar de este lado? Así que vació el cargador a los esbirros en uniforme, y desde entonces estaba con los buenos. (p. 34)

La frase leitmotiv del Pocho aparece como un quiasmo que establece un cruce entre los términos, jugando con las fronteras del lenguaje y produciendo una inversión de la consabida traición del pocho. Así, vemos que según el punto de vista que Lobo expresa en sus corridos, el Rey le concede al Pocho la oportunidad de enmendar la traición, de elegir el buen bando (y encontrarse del buen lado de la frontera), y todo esto expresado en términos de heroicidad del Rey, de disyuntiva, iluminación y revelación. Vemos que a estas alturas el Artista se complace en esta inversión de valores que opera el mundo del Rey, en el que «los buenos» se encuentran de su lado y, por consiguiente, todos los que se encuentran fuera de ese mundo (esencialmente todo lo que representa la legitimidad estatal) se encuentran del lado del mal.

Así como Lobo no comprende las reglas de la ciudad sórdida y despiadada de la cual él cree que lo salvó el Rey, tampoco maneja los códigos de ese nuevo mundo en el que está incursionando. De hecho, las referencias culturales de occidente escapan de su espectro de comprensión pero también son distorsionadas por la ostentación kitsch del mundo del narcotráfico. La descripción del lujo desmedido de los jardines del Rey lo pone en evidencia:

Salieron a los jardines, pasaron junto a una fuente en cuyo centro un dios con tenedor tiraba agua por la boca, siguieron por el laberinto de arbustos trazado con las letras del nombre del Rey, [...] una alberca se ornaba con mosaicos de hoja de 
yerba al fondo [...] Luego miró más allá, hacia el fin del jardín, la reja electrificada, el desierto; [...]. Caminaron hasta donde estaba la colección del Rey. Había serpientes, tigres, cocodrilos, un avestruz, y en una jaula más grande, casi un jardín, un pavo real. (pp. 51-52)

En ese minizoológico digno del propio Moctezuma, cabe destacar no sólo la reja electrificada, como eco de la frontera, sino también al pavo real preso también dentro de una jaula. Esta imagen funciona como una especie de mise en abyme con carácter proléptico: el palacio es también una cárcel; el pavo real se asimilaría con facilidad al Rey por su capacidad de encandilamiento cuando se pavonea con su cola abierta. Sin embargo, esta imagen permite otra interpretación. En efecto, podría ser leída también como reflejo del mismo Lobo, del Artista, preso dentro de una jaula dorada: él será una presa más en el zoológico del Rey y la onomástica vendría a recalcar aún más el juego de contradicciones. El Artista no desempeñará el papel de depredador al que lo hubiera podido predestinar su nombre sino más bien al contrario, se ve acorralado en ese universo. Sin embargo, la lectura de un Lobo como especie acorralada también puede ser operativa.

Así, desde el inicio de la novela, Lobo va percibiendo que ese mundo que se le aparece armonioso y justo reproduce las fallas del mundo que lo contiene. Sin embargo, no cobra plena conciencia de ello hasta casi llegando al desenlace de la novela. Este equívoco se aprecia en la descripción del palacio del Rey contrastado con la ciudad. En efecto, entre ambos se erige una frontera interna que ya era visible en el pasaje anterior:

Él había andando por estos rumbos hacía mucho, con sus padres todavía. Pero en ese entonces era un basural, una trampa de infección y desperdicios. Qué iba a sospechar que se convertiría en un faro. [...] Al acercarse, el Palacio reventaba en un confín del desierto en una soberbia de murallas, rejas y jardines vastísimos. Una ciudad con lustre en la margen de la ciudad, que sólo parecía repetir calle a calle su desdicha. (p. 20)

Nuevamente tenemos la connotación de la luminosidad en torno al mundo del Rey, aquí el palacio. La mención de las murallas y las rejas refuerza la idea de la existencia de una frontera interna. Sin embargo, el texto también alude a una imagen en espejo, y una continuidad, entre ese «faro» y las calles de la ciudad, con lo cual la frontera entre el pasado de inmundicia de donde surge el palacio y el presente fausto no es tan obvio. En efecto, una segunda lectura del «basural», de la «trampa de infección y desperdicios» se aplicaría perfectamente al mundo del narcotráfico al que remite el texto. Así pues, «no es oro todo lo que reluce» y de esto toma conciencia Lobo ya casi llegando al final de la novela cuando lleva a su amada, la Cualquiera, a pasear a la ciudad. Se aprecia el cambio de perspectiva que se da en el Artista:

Con regocijo de feria le señaló [La Cualquiera al Artista] en cada antro una imagen favorita: una rocola del año del caldo, un cantinero con ojos de tortuga, una barra de madera labrada de obscenidades, un conjunto musical de puros enanos, un baño con mujeres paradas para mear. [...]. Sí vio cosas nuevas, sin embargo, o las mismas cosas se le revelaron con una fuerza nueva, como si se le hubiera despellejado un callo en la mirada y ahora todo su ser se fijara en pormenores que antes se perdían en un foto borrosa. Les miró el nervio herido a las clandestinas y el hartazgo a las cautivas, entendió el frío del viejo que gemía desde el suelo sin poder articular una petición; y un cartel que preguntaba por una muchachita extraviada le hizo concebir el horror de ser torturado por cobardes. (pp. 79-80)

Esta nueva mirada cruda sobre el horror se detiene en la situación de la mujer en esa sociedad hipermachista que la cosifica en grado sumo y la referencia a las desaparecidas de Juárez aparece apenas velada. Por otro lado, el Artista es también objeto de 
cosificación ya que es utilizado (él y su arte) para cumplir una serie de fines determinados por el Rey: no sólo su propia promoción sino también la búsqueda de información usando al Artista como espía. Él es también una presa más en ese universo, la contradicción de la onomástica se hace evidente cuando el Rey lo condena por haber revelado su debilidad a través de sus corridos: el Rey no puede concebir. Sin embargo, al llegar al desenlace se invierten nuevamente los papeles (o se rectifican) pues el Artista recupera su nombre cuando decide dejar el universo del Rey y este último será atrapado y reemplazado por el Heredero. La imagen del pavo real volverá a cobrar importancia en este sentido pues será ejecutado sin razón aparente, a manera de símbolo cuya lectura permanece abierta así como otros símbolos, como el nombre del personaje, como ha sido apuntado.

Si bien el Artista, Lobo, vuelve a ser denominado por su nombre en el último capítulo, la Cualquiera jamás es nombrada con el suyo. Los personajes femeninos son la «atroz encarnación de la condición femenina» ${ }^{21}$. Peor que ser Ninguno es ser Ninguna: La Niña y La Cualquiera son víctimas por antonomasia de la violencia ejercida sobre las mujeres en un universo patriarcal y violento como lo es el del narcotráfico. Lobo, por su parte, hará honor a su nombre al verse condenado a la soledad, cual lobo estepario, o más bien fronterizo... En efecto, La Cualquiera, que en el último capítulo es denominada «Ella» (en algo mejora su condición), se va a un destino incierto (¿del otro lado?), mientras que Lobo se queda. Sin embargo, al decidir abandonar la corte del Rey, su mirada se ha afinado más que su acordeón.

En la siguiente novela de Yuri Herrera, Señales que precederán al fin del mundo ${ }^{22}$, la heroína enmendará con creces los destinos de La Niña, La Cualquiera y hasta de Azucena, la única mujer del ejército de los iluminados, que sólo estuvo de adorno.

Como bien lo señala su título, esta novela de Yuri Herrera aparece bajo el signo del Apocalipsis, aunque más bien se trate de una serie de signos que lo anuncian. Los títulos de algunos de los capítulos remiten a la cultura prehispánica («El Cerro de Obsidiana», por ejemplo), lo cual aunado al sentido profético del título, con la referencia a los «presagios funestos» de los aztecas, hace que el paratexto establezca una pauta de lectura con una base mitológica. Sin embargo, sobre este andamiaje se construye una narración de corte más bien realista pautada no sólo por etapas (o más bien por una serie de pruebas) que tendrá que ir enfrentando Makina, la protagonista, para poder cruzar del otro lado y encontrar a su hermano, sino también por una serie de visiones que irá descifrando poco a poco. En efecto, Makina vivirá en carne propia el proceso de ir transformándose en otra a través de la experiencia del cruce de una frontera concreta y de otra frontera más bien mental. Su primer objetivo, ir en busca de su hermano para hacerlo volver con ella a casa, poco a poco va dejando el paso a otro designio para Makina. El periplo transfronterizo culmina con una trasmutación o con el cambio de piel de Makina y con el inicio de un nuevo ciclo.

51 La temática de la frontera se centra más bien en la experiencia de lo fronterizo. Tal como lo expresa el autor a propósito de esta novela,

[...] es menor el trabajo con la frontera que con lo fronterizo. Los personajes están pasando por ahí y se están transformando y al transformarse están también transformando el lugar [...]. Lo fronterizo me importa en términos de cómo se diluyen nuestras certezas ${ }^{23}$.

De hecho, esta experiencia de lo fronterizo aparece en la forma en que Makina percibe ese nuevo espacio, esa nueva lengua, esa nueva gente y otra serie de visones en las que, en efecto, se van diluyendo no sólo sus certezas sino las del lector. Como en Trabajos del reino, 
Yuri Herrera juega nuevamente con la omisión de topónimos o términos concretos, aunque utiliza un par de topónimos pertenecientes al habla popular y que permiten situar alguna coordenadas geográficas. Así, el periplo de Makina va de «El Pueblo» a «La Ciudadcita», para luego detenerse en «El Gran Chilango» y finalmente llegar «al gabacho». Los personajes tienen nombres codificados, como los esbirros que preparan los aspectos materiales de la travesía a cambio de favores ilegales (el señor Dobleú, el Señor Hache o el Señor Q); o no lo tienen nunca, como la hermanita o el hermano. Sólo Makina, su madre (la Cora) y Chucho, el «coyote» que la ayuda a cruzar el río a nado y a atravesar el desierto, aparecen con nombres propios.

El incipit pone en escena lo que sería la primera señal del cataclismo. En efecto, Makina se encuentra en La Ciudadcita, que de repente se ve sacudida por un terremoto: la tierra se abre y se traga a los transeúntes como si el inframundo estuviera reclamando lo suyo. Makina se salva por milagro: «Pinche ciudad ladina, se dijo, Siempre a punto de reinstalarse en el sótano. Era la primera vez que le tocaba locura telúrica. La Ciudadcita estaba cosida a tiros y túneles horadados por cinco siglos de voracidad platera [...]» (pp. 11-12). El terremoto, como presagio, forma parte de la base mítica de la novela pero al mismo tiempo remite a la realidad concreta de la explotación minera y sus consecuencias. Esa Ciudadcita podría ser cualquier ciudad minera de cualquier punto del país.

La «locura telúrica» también sirve de trasfondo para otra construcción simbólica que se va afianzando con elementos que se despliegan en las siguientes páginas. En efecto, nos enteramos de que Makina se gana la vida como telefonista; las reglas que ella se aplica a sí misma en su trabajo («Una es la puerta, y no la que cruza la puerta»), así como las lenguas que maneja, aportan otras pistas. Es de notar que también se da la omisión de los nombres de los idiomas:

A veces era gente de pueblos de por ahí que llamaba y ella contestaba en lengua o en lengua latina. A veces, cada vez más, llamaban del gabacho; éstos frecuentemente ya se habían olvidado de las hablas de acá y ella les respondía en la suya nueva. Makina hablaba las tres, y en las tres sabía callarse. (p. 19)

La protagonista es intermediaria en este dispositivo tripartita en el que podemos percibir el juego de tensiones entre una cultura indígena (lengua), una cultura hispánica (lengua latina) y la anglosajona (el gabacho). Se trata de un juego de fuerzas contrarias que hacen eco con la locura telúrica en medio de la cual Makina se encuentra y que es la primera señal del giro que tomará su vida. Las circunstancias harán que tenga que dejar de ser puerta y optar por la acción: el cruce. Este terremoto hace pensar en las características que Lester Langley dio a Mexicamérica ${ }^{24}$ al hablar de esta entidad geográfica y cultural en términos de placas tectónicas:

Al sureste de la ciudad de los aztecas se encuentra el México indio, otro mundo. El México indio presiona desde el sur para recordarle al México moderno las raíces culturales de la nación; los Estados Unidos presionan desde el norte para recordarle las realidades económicas y extraer ventajas políticas. La fuerza de estas presiones contrarias y contradictorias, sentida desde hace mucho tiempo al sur de la frontera, se ha desplazado hacia el norte ${ }^{25}$.

El texto sugiere que ese juego de tensiones tiene que resolverse y que la resultante será encarnada por una joven mujer. El género masculino no cuenta con una imagen muy edificante en la obra de Herrera y Señales... lo corrobora. Un vez más la figura paterna es invisible y causante de la ida del hermano, que se va al otro lado a recuperar una supuesta tierra que evidentemente nunca se concretizó: «un terrenito allá, del otro lado del río, 
que les había dejado un señor. El papel decía un nombre que podía ser el del que había sido su padre antes de desaparecer mucho tiempo atrás, [...]» (p. 31). De hecho, si la Cora le asigna a Makina la misión de encontrar a su hermano es porque, como ella lo dice, «a quién se [la] voy a confiar ¿a un hombre?» (p. 12): no sólo no son de fiar sino que además no los hay. Evidentemente, esto es reflejo de una realidad socioeconómica que ha producido el éxodo masivo de los hombres hacia los EEUU. Los hombres aparecen en la novela sólo para bajar la mirada ante Makina, para intentar abusar de ella antes de que ésta les tuerza los dedos de las manos o para «desgranarla» con ella, si así lo decide ella. Sólo Chucho escapa a esta hecatombe de género al ser digno de gracia ante los ojos de Makina y al ser el que la acompaña en el cruce concreto del río y otro cruce más simbólico que se da en el desenlace de la novela.

Los esbirros que planean el cruce de Makina no dejan de cuestionarse sobre las intenciones de ésta. Preguntan «¿vas a cruzar?» de forma recurrente, como si ese rito de iniciación no le pudiera estar reservado a ésta. En efecto, Makina tendrá que enfrentar más de una prueba, incluso esquivar un tiroteo para alcanzar su meta. Al igual que en Trabajos... la protagonista debe superar un rito de iniciación que encuentra su cimiento en la realidad de la frontera: «Mexamérica es un absurdo con códigos propios: del otro lado hay trabajos disponibles, pero la mano de obra debe superar ritos de iniciación que dejarían satisfecha a la tribu más estricta» ${ }^{26}$.

Pero antes de llegar a la frontera, Makina pasa por El Gran Chilango, que aparece como emblema de cruce o tránsito entre dos mundos:

Cada vez que volvía al Gran Chilango plantaba el pie suavecito porque no era ése el sitio donde quería dejar huella [...]. Por eso prefirió viajar bajo tierra para llegar a la otra central camionera. [...] ahí abajo ni la hería el aire denso ni se arriesgaba a la fascinación. (p. 27)

Makina se niega a ceder a la presión del centro hegemónico que es México DF, pero tampoco querrá ceder a la hegemonía del gran vecino del norte. Sin embargo, allí la jugada de esquive no será tan sencilla como tomar una ruta subterránea, pasando de prisa, para no ceder a la tentación de la modernidad que quema los pulmones. En este sentido el personaje de Makina se construye con otros elementos propios de lo fronterizo. Michael Kearney considera que la migración no se limita a procesos de expulsión y recepción de trabajadores, sino que implica la separación nacional de los sitios de producción y reproducción de la fuerza de trabajo. De esta manera las comunidades transnacionalmente constituidas trascienden los límites de poder de cada Estado nacional. Por ello, la frontera se convierte en un sitio liminal donde se forman signos de identidad ajenos a los definidos por los estados nacionales ${ }^{27}$. La forma en que Makina expresa su paso por la capital puede ser vista como una forma de trascender esos límites del poder hegemónico y la conformación en su persona de lo transnacional. El resto de los eventos va en ese sentido. Sin embargo, antes de aceptar su ser «transnacional», Makina se aferra al Pueblo. Ella ve su periplo como algo transitorio cuyo fin es regresar:

Ya había arreglado lo del cruce y cómo hallaría a su hermano, ahora quería asegurarse de que habría quién la ayudara a volver; no quería ni quedarse por allá ni que le sucediera como a un amigo suyo que se mantuvo lejos demasiado tiempo, tal vez un día de más o una hora de más, en todo caso lo bastante de más como para que le pasara que cuando volvió todo seguía igual pero ya todo era otra cosa, o todo era semejante pero no era igual: su madre ya no era su madre, sus hermanos ya no eran sus hermanos, eran gentes de nombres difíciles y gestos improbables, como si los hubieran copiado de un original que ya no existía; hasta el aire, dijo, le entibiaba el pechote otro modo. (p. 21) 
Para no sucumbir a esta jugarreta propia del exilio que trastoca la temporalidad haciéndola sumamente relativa (Gardel dijo que 20 años no es nada), Makina cree conjurarla preparando una mochila que podríamos calificar como «de la transitoriedad». En ella lleva lo indispensable para un fin de semana, pero lo que cabe resaltar de este elemento prosaico es más bien el cariz poético da la descripción del contenido de la mochila. Se trata de una enumeración de objetos y sus finalidades, organizada en frases sin mayúsculas y sin puntos, cual versos libres que culminan con una frase binaria: «Ella se iba para nomás volver, por eso llevó a penas estas cosas» (pp. 56-57). Se trata de una relación causal que da a la protagonista la impresión de tener cierto control sobre el acontecer de su vida. El cruce del río será otra señal de que las cosas no son siempre como uno las prevé:

No supo cuánto tiempo se debatió confusamente, hasta que el pánico se le pasó e intuyó que daba lo mismo hacia dónde o a qué velocidad se dirigía, que finalmente llegaría a donde debiera llegar. [...] Apenas habían sido una decenas de metros, pero al mirar el cielo a Makina le pareció que era ya otro, más lejano o menos azul. (p. 43)

Este pasaje de la novela es uno de los que establecen el paralelo entre la frontera concreta y otra más sutil. Sobre el relato «Los Brothers» del tijuanense Federico Campbell, Juan Villoro afirma que su gran logro «consiste en transformar a la frontera, de categoría geográfica en categoría psicológica; en cualquier sitio hay una región limítrofe interior, una Tijuana de la mente que nos condena a avanzar sin brújula» ${ }^{28}$. Este logro se aplica perfectamente también a Señales...; la ausencia de brújula puede ser vista como esas señales que se le aparecen a Makina y que ella tiene que interpretar. Se trata de una señal en negativo que sugiere que nada está verdaderamente trazado, comenzando por esa frontera concreta que se dispone a atravesar.

La primera visión de Makina tras haber cruzado la frontera es más bien una especie de espejismo. Donde la chica cree percibir una mujer embarazada debajo de un árbol («pensó que ése era buen augurio [...] un país donde una que anda de cría camina por el desierto y se echa a dejar que éste le crezca sin ocuparse de nada más», p. 47), resulta haber, conforme se va afinando la visión, un muerto inflado y devorado por zopilotes (p. 48). Makina descubrirá un universo igual de despiadado que el que dejó atrás. La continuidad entre los dos mundos no es el único descubrimiento sino también lo transitorio de cada uno y de la existencia en general. Este aspecto lo encontramos en otra visión que tiene lugar después de que se libra de las balas de la policía. Makina observa un copo de nieve:

[...] se preguntó cómo es que algunas cosas del mundo, algunos países, algunas personas, podían parecer eternas si todo era como ese diminuto palacio de hielo: irrepetible, precioso y frágil. Sintió una súbita decepción pero también se le quitó algo del miedo que se le había ido acumulando desde que había jarchado de casa. (p. 61)

61 Si bien todo es efímero e irrepetible, es inútil aferrarse a ello, tal es la enseñanza que debe adquirir Makina, que bien podría encontrarse en este momento en Nepal y no en Tijuana $\mathrm{u}$ otra ciudad fronteriza. Todo lo que cree cierto se diluye como ese copo de nieve, incluyendo ese origen que cree que determina su identidad, una identidad que se le antojaba inmutable e irrepetible. Pero a partir de este momento, Makina comienza a percibir las señales que todo es también movimiento y transformación. He aquí lo fronterizo como categoría que determina el devenir del personaje.

Lo fronterizo se declina en distintos aspectos de esa nueva realidad que Makina descubre. En un primer momento tenemos la percepción del espacio y de sus habitantes: 
La ciudad era un arreglo nervioso de partículas de cemento y pintura amarilla. Carteles de prohibición hormigueaban calle a calle inspirando a los nacionales a verse siempre protegidos, seguros, amables, inocentes, soberbios, intermitentemente azorados, livianos y desbordantes; sal de la única tierra que vale la pena conocer. [...]. En medio del llano de concreto y varilla, sin embargo, luego luego sintió otra presencia, espolvoreada como remaches caídos de una ventana: en las esquinas, en los andamios, en la banqueta; efímeras miradas de reconocimiento que de inmediato se ocultaban para convertirse en huida. Era el paisanaje armado de chambas: albañiles, vendedores de flores, estibadores, choferes; depurando el disimulo para no delatar ningún propósito común sino nomás, nomás, nomás: que estaban allí para recibir órdenes. Eran como allá pero menos chifladores, y ninguno pordioseraba. (pp. 62-63)

Se trata de una descripción en la que Herrera juega con la frontera entre un registro poético y otro popular, produciendo un cuadro de luz y sombra que llama a afinar la mirada para discernir los detalles de este mundo semejante al de los Eloi y los Morlocks de Wells. Si bien esta imagen traduce la segregación entre dos grupos que cohabitan sin mezclarse, la cohabitación y la mezcla sí que se percibe en otros ámbitos de la realidad circundante. Primeramente se trata de uno de los que mejor se presta para cruces e innovaciones, a saber la comida:

Algo menos preciso la requebró al andar por los restoranes: dulzuras y chilosidades inauditas, mescolanzas que jamás le habían pasado por la nariz o el paladar, frituras delirantes. Eran sitios de comida remota, pero no dejaba de haber entremedio algo familiar, algo sabido en la manera de llegar al punto en los platos. [...] Toda la cocina es cocina mexicana, se dijo. Y luego se dijo Já. No era así, pero igual le había gustado decirlo. (pp. 63-64)

No solamente se aprecia el aire triunfal del personaje sino también es relevante notar que se trata del primer, y único, uso del gentilicio en todo el texto. La revancha de la comida mexicana, que finalmente no es tal pues convive con otros aromas y sabores, es reflejo de la forma en que México se reapropia del espacio fronterizo. Sin embargo, se trata de un simulacro de victoria, como bien lo reconoce el personaje y como lo confirma la expansión del Tex-Mex por todo el planeta. Finalmente el mejor ejemplo de la mudanza que encarna la frontera la hallamos en la forma en la que el texto nos pinta la nueva lengua que va surgiendo en ella:

Son paisanos y son gabachos y cada cosa con una intensidad rabiosa; [...]. Hablan una lengua intermedia con la que Makina simpatiza de inmediato porque es como ella: maleable, deleble, permeable, un gozne entre dos semejantes distantes y luego entre otros dos, y luego entre otros dos, nunca exactamente los mismos, un algo que sirve para poner en relación. [...] es una franja difusa entre lo que desaparece y lo que no ha nacido. Pero no una hecatombe [...]. Al usar en una lengua la palabra que sirve para eso en la otra, resuenan los atributos de la una y de la otra: si uno dice Dame fuego cuando ellos dicen Dame una luz, ¿qué no se aprende sobre el fuego, la luz y sobre el acto de dar? No es que sea otra manera de hablar de las cosas: son cosas nuevas. Es el mundo sucediendo nuevamente, advierte Makina: prometiendo otras cosas, significando otras cosas, produciendo objetos distintos. (pp. 73-74)

Se trata de un pasaje denso de significado y de ecos con otros momentos de la narración. Por un lado Makina se da cuenta de que se puede ser puerta (gozne) y el que la cruza al mismo tiempo, que ese «entre dos» entre lo sólido y lo líquido del copo de nieve no es el fin del mundo, sino el fin de un mundo y el paso a otro nuevo. La frontera, sus habitantes y su habla reproducen el eterno ciclo de encuentro y desencuentro de culturas a lo largo de la Historia: es el sitio del movimiento eterno de la vida. Por otro lado se trata de un ciclo 
repetitivo por el cual la realidad se transmuta sin dejar de ser: la ley de la materia hecha ficción.

La imagen de la frontera, tal como aparece en este pasaje, y en la novela en general, hace pensar en lo que Serge Gruzinski denominó la realidad «fractal» ${ }^{29}$, refiriéndose al periodo de diez años aproximadamente entre la Conquista y época colonial. Se trata de formas sociales extrañas que se caracterizan por su aspecto caótico y su inestabilidad, por sus mutaciones imprevistas y su heterogeneidad, lo que los cronistas llamaron «novedad» o «behetría» ${ }^{30}$. Esta particularidad de la frontera la encontramos plasmada en la obra de otros autores cuyas obras se centran en ese espacio geográfico y cultural. Por ejemplo, sobre la novela del tijuanense Luis Humberto Crosthwaite, La luna siempre será un amor difícil, en la que un soldado del siglo XVI llega al México del TLC y termina trabajando en una maquiladora, nos dice Juan Villoro: «La metáfora es nítida: el radical encuentro de dos mundos no sólo ocurrió en la Historia lejana sino también ayer, y tiene un escenario primordial: la frontera» ${ }^{31}$. Es ese escenario primordial el que Yuri Herrera elije a su vez para hacer su propia lectura de esta fusión temporal.

más que amalgama de tiempos, el énfasis es puesto en el correr y en el proceso mismo del suceder del tiempo. Llegando al desenlace Makina es guiada por Chucho a un antro (otro inframundo) custodiado por un letrero que dice Jarcha. Ya se ha señalado como particularidad de la obra de Herrera la creación de un nuevo lenguaje. El término «jarcha», que proviene del árabe, significa «salida» y designa el final de un tipo de composición musical medieval. Herrera crea el verbo «jarchar», que ha venido pautando todas estas páginas, que implica el proceso mismo de irse, pero con una tonalidad especial que le da algo de definitivo y transitorio al mismo tiempo, por su referencia al lenguaje de la frontera y por su significado. Makina desciende una escaleras, diciéndose sin cesar, «algo va a pasar, algo va a pasar»; lo único que oye (y pasa) es «el sonido del agua corriendo» [...] «el correr enérgico de ríos subterráneos» (p. 118) y recibe un paquete: «Makina tomó el legajo y miró su contenido. Ahí estaba ella, con otro nombre y otra ciudad de nacimiento. Su foto, nuevos números, nuevo oficio, nuevo hogar. Me han desollado, musitó» (pp. 118-119), como si hubiera sido víctima de un sacrificio dedicado a Xipe Totec. Se trata del momento de culminación de su cambio de piel al cabo del cual Makina logra aprehender otra enseñanza con la cual se cierra la novela:

[...] dejó de sentir la pesadez de la incertidumbre y de la culpa: evocó a su gente como a los contornos de un paisaje amable que se difumina, el Pueblo, la Ciudadcita, el Gran Chilango, aquellos colores, y entendió que lo que le sucedía no era un cataclismo; lo comprendió con todo su cuerpo y con toda su memoria, lo comprendió de verdad y finalmente se dijo Estoy lista cuando todas las cosas del mundo quedaron en silencio. (p. 119)

El fin del mundo no es más que una jarcha: termina una canción y hay otra cuya sonoridad ya se escucha, como ese correr del agua que no cesa. Se trata de otro ciclo que comienza y que Makina debe abordar sin temores. La experiencia individual de la protagonista es al mismo tiempo una experiencia global. La frontera cristaliza la experiencia del devenir de nuestras sociedades de principios de este milenio en las que estamos sometidos a cambios incesantes. No es de extrañar que un imaginario que va más allá del mexicano se la haya apropiado para expresar sus propias inquietudes.

69 Si bien es cierto que la realidad de la frontera es tan diversa y heterogénea que no se puede abarcar como un todo unívoco, un discurso literario o una producción artística que se apropie esa realidad no tiene por qué ser garante de autenticidad referencial. El «qué» 
es pre(texto) para un «cómo» y un «por qué». Todo el subcontinente ha visto marcada su identidad cultural por su relación particular con EEUU. Otros países latinoamericanos poseen su propia historia fronteriza con el gran vecino del norte, con su propia carga emocional y repercusiones culturales, ya sea una Cuba separada por pocos kilómetros en balsa, ya sea un Panamá con una frontera interna durante todo el siglo xx. Sin embargo, la dimensión y el carácter concreto de la frontera México-EEUU la convierten en sitio privilegiado de proyección de la problemática relación con EEUU, tanto para los países latinoamericanos como para la gran comunidad hispana afincada en ese país. La frontera norte de México es sitio de cristalización del des(encuentro) entre el Norte y el Sur para todo un imaginario colectivo, que va más allá del mexicano para abarcar al resto de América Latina ${ }^{32}$ : «la idea de frontera en este caso, alcanza un territorio mucho más amplio que Aztlán no puede abarcar» ${ }^{33}$. Desde 1989 (fecha que no sólo remite a la caída del muro de Berlín sino también a la invasión de Panamá por EEUU, dos modos de derribar fronteras), vivimos una nueva era de confrontación, ya no entre el este y el oeste, sino entre el norte y el sur. En esta época de cruce de mundos y de fronteras, la novela sigue cumpliendo el cometido de escrutar el modo operativo de nuestras sociedades y la nueva misión del escritor y la literatura.

\section{BIBLIOGRAFÍA}

\section{Textos de referencia}

HERRERA Yuri, Trabajos del reino, Barcelona, Editorial Periférica, 2010 (1. ${ }^{\text {ra }}$ edición 2004).

-, Señales que precederán al fin del mundo, Barcelona, Editorial Periférica, 2010.

ToscanA David, El ejército iluminado, México, Tusquets editores, 2006.

\section{Otros}

BRESCIA Pablo y BENNET Scott, «¿Nueva Narrativa? Entrevista con David Toscana», Mexicain Studies / Estudios Mexicanos, vol. 18, n. ${ }^{\circ}$ 2, 2002, pp. 351-362.

CEBALLOS RAMÍREZ Manuel, «Consideraciones históricas sobre la frontera norte mexicana», en J. M. Valenzuela Arce (coord.), Por las fronteras del norte. Una aproximación cultural a la frontera México-Estados Unidos, México, Biblioteca mexicana, 2003, pp. 71-87.

GRUZINSKI Serge, «Las repercusiones de la conquista: La experiencia novohispana», en Carmen Bernard (ed.), Descubrimiento, conquista y colonización de América a quinientos años, México, Fondo de Cultura Económica, 1994.

LOMELí Francisco, «En torno a la literatura de la frontera: ¿Convergencia o divergencia?», Plural: Revista Cultural de Excelsior, vol. 15-16, n. ${ }^{\circ} 179,1986$, pp. 24-32.

PAZ Octavio, El laberinto de la soledad, Madrid, Cátedra, 2003. 
PAZ SOLDÁN Edmundo, «Entre la tradición y la innovación: globalismos locales y realidades virtuales en la nueva narrativa latinoamericana», en Eduardo Becerra (ed.), Desafíos de la ficción, Alicante, Cuadernos de América sin Nombre, 2002, pp. 56-66.

-, «El artista en la corte», El Boomeran(g), mayo 2010, consultable en línea: < www.elboomeran.com/blog-post/117/9014/edmundo-paz-soldan/el-artista-en-la-corte/> (consultado el 13/01/2013).

RODRÍGUEZ LOZANO Miguel, «La otra experiencia del norte: Aproximación a la narrativa de David Toscana», Revista de Literatura Mexicana Contemporánea, vol. 4, n. ${ }^{\circ}$ 10, 1999, pp. 57-66.

RUISANCHEz Ramón, Señales de la región, sin fecha, consultable en línea: <http://fr.scribd.com/ doc/93840810/Jose-Ramon-Ruisanchez-Senales-de-region> (consultado el 13/01/2013).

SARAVIA QUIRÓz Leobardo, «Contexto regional de la creación literaria en la frontera», en Aralia López González (ed.), Mujer y literatura mexicana y chicana: Culturas en contacto, México/Tijuana, Colegio de México/Colegio de la Frontera Norte, 1990, pp. 189-194.

TABUENCA María Socorro, «Reflexiones sobre la literatura de la frontera», Puentelibre: Revista de Cultura, vol. 4, 1995, pp. 8-12.

-, «Las literaturas de la frontera», en J. M. Valenzuela Arce (coord.), Por las fronteras del norte. Una aproximación cultural a la frontera México-Estados Unidos, México, Biblioteca mexicana, 2003, pp. 393-427.

VALENZUELA ARCE José Manuel (coord.), Por las fronteras del norte. Una aproximación cultural a la frontera México-Estados Unidos, México, Biblioteca mexicana, 2003.

-, «Centralidad de las fronteras. Procesos socioculturales en la frontera México-Estados Unidos», en J. M. Valenzuela Arce (coord.), Por las fronteras del norte. Una aproximación cultural a la frontera México-Estados Unidos, México, Biblioteca mexicana, 2003, pp. 33-67.

VILLORO Juan, «Entrevista con Juan Villoro», Cuadernos hispanoamericanos, n. ${ }^{\circ}$ 561, marzo 1997, pp. 119-124.

-, «Iguanas y dinosaurios. América Latina como utopía del atraso», Efectos personales, México, Era, 2000, pp. 87-93.

-, «Nada que declarar. Welcome to Tijuana», Letras Libres, vol. II, n. ${ }^{\circ}$ 17, mayo 2000, pp. 16-20, consultable en línea: <www.letraslibres.com/revista/convivio/nada-que-declarar-welcometijuana> (consultado el 06/01/2013).

-, «El juego de las identidades cruzadas», en Walter Berg y Vittoria Borsó (eds), Unidad y pluralidad de la cultura latinoamericana: Géneros, identidades y medios, Madrid/Frankfurt, Iberoamericana/Vervuert, 2006, pp. 19-30.

-, «Mexicamérica: La frontera de los ilegales. La literatura y la frontera», sin fecha, consultable en línea: <www.zonezero.com/magazine/essays/distant/zmexi.html> (consultado el 18/12/2012). ZUNINI Patricio, «Escrito en la frontera. Entrevista al escritor mexicano Yuri Herrera, autor de Los trabajos del reino y Señales que precederán al fin del mundo", Eterna cadencia, junio 2011, consultable en línea: <http://blog.eternacadencia.com.ar/?p=14235> (consultado el 11/01/2013). 


\section{NOTAS}

1. J. M. Valenzuela Arce, «Centralidad de las fronteras. Procesos socioculturales en la frontera México-Estados Unidos», en Por las fronteras del norte. Una aproximación cultural a la frontera MéxicoEstados Unidos, México, Biblioteca mexicana, 2003, pp. 33-34.

2. Ibid., p. 41.

3. J. Villoro, «Mexicamérica: La frontera de los ilegales. La literatura y la frontera», consultable en línea: <www.zonezero.com/magazine/essays/distant/zmexi.html>, sin fecha.

4. Ibid.

5. J. Villoro, «El juego de las identidades cruzadas», en Walter Berg y Vittoria Borsó (eds), Unidad y pluralidad de la cultura latinoamericana: Géneros, identidades y medios, Madrid/Frankfurt, Iberoamericana/Vervuert, 2006, p. 20.

6. Ibid., p. 22.

7. J. Villoro, «Iguanas y dinosaurios. América Latina como utopía del atraso», Efectos personales, México, Era, 2000, p. 89.

8. Ibid., p. 91.

9. M. Rodríguez Lozano, «La otra experiencia del norte: Aproximación a la narrativa de David Toscana», Revista de Literatura Mexicana Contemporánea, vol. 4, n. ${ }^{\circ}$ 10, 1999, p. 62.

10. Ibid., p. 61.

11. J. M. Valenzuela Arce, «Centralidad de las fronteras. Procesos socioculturales en la frontera México-Estados Unidos», art. cit., p. 34.

12. Ibid., p. 35.

13. D. Toscana, El ejército iluminado, México, Tusquets editores, 2006.

14. En El perfil del hombre y la cultura en México, publicado en 1934.

15. M. Ceballos Ramírez, «Consideraciones históricas sobre la frontera norte mexicana», en J. M. Valenzuela Arce (coord.), Por las fronteras del norte. Una aproximación cultural a la frontera MéxicoEstados Unidos, México, Biblioteca mexicana, 2003, p. 80.

16. P. Brescia y S. Bennet, «¿Nueva Narrativa? Entrevista con David Toscana», Mexicain Studies / Estudios Mexicanos, vol. 18, n. ${ }^{\circ}$ 2, 2002, p. 358.

17. Ibid., p. 359.

18. Y. Herrera, Trabajos del reino, Barcelona, Editorial Periférica, 2010 (1. ${ }^{\text {ra }}$ edición 2004).

19. J. Villoro, «Nada que declarar. Welcome to Tijuana», Letras Libres, vol. II, n. ${ }^{\circ} 17$, mayo 2000 , consultable en línea <www.letraslibres.com/revista/convivio/nada-que-declarar-welcometijuana>, sin página.

20. J. M. Valenzuela Arce, «Centralidad de las fronteras. Procesos socioculturales en la frontera México-Estados Unidos», art. cit., p. 39.

21. O. Paz, El laberinto de la soledad, Madrid, Cátedra, 2003, p. 224.

22. Y. Herrera, Señales que precederán al fin del mundo, Barcelona, Editorial Periférica, 2010.

23. P. Zunini, «Escrito en la frontera. Entrevista al escritor mexicano Yuri Herrera, autor de Los trabajos del reino y Señales que precederán al fin del mundo», Eterna cadencia, junio 2011, consultable en línea <http://blog.eternacadencia.com.ar/?p=14235>, sin página.

24. Se trata de la definición de Lester D. Langley en Mexamérica. Dos países, un futuro, Fondo de Cultura económica, 1994: «región cultural que abarca desde California hasta Texas y los estados del norte mexicano, y su capital es la ciudad de Los Ángeles, aunque también podría ampliarse hasta Chicago y Pittsburgh por el lado estadounidense y hasta la capital por el lado mexicano» (cit. en J. M. Valenzuela Arce, «Centralidad de las fronteras. Procesos socioculturales en la frontera México-Estados Unidos», en Por las fronteras del norte. Una aproximación cultural a la frontera México-Estados Unidos, México, Biblioteca mexicana, 2003, p. 46). 
25. L. D. Langley, Mexamérica. Dos países, un futuro, Fondo de Cultura económica, 1994, p. 18, citado por J. M. Valenzuela Arce, en «Centralidad de las fronteras. Procesos socioculturales en la frontera México-Estados Unidos», art. cit., p. 47.

26. J. Villoro, «Nada que declarar. Welcome to Tijuana», art. cit., sin página.

27. M. Kearney, «Fronteras fragmentadas, fronteras reforzadas», en G. Mummert (comp.), Fronteras fragmentadas, El Colegio de Michoacán, Centro de Investigación y Desarrollo del Estado de Michoacán, Zamora, Mich, 1999, pp. 559-571, citado por J. M. Valenzuela Arce, en «Centralidad de las fronteras. Procesos socioculturales en la frontera México-Estados Unidos», art. cit., p. 50.

28. J. Villoro, «Mexicamérica: La frontera de los ilegales. La literatura y la frontera», art. cit.

29. Término utilizado en las ciencias exactas para designar fenómenos irregulares, fragmentados y que no pueden ser reducidos a formas enteras y sencillas.

30. S. Gruzinski, «Las repercusiones de la conquista: La experiencia novohispana», en Carmen Bernard (ed.), Descubrimiento, conquista y colonización de América a quinientos años, México, Fondo de Cultura Económica, 1994, p. 151.

31. J. Villoro, «Mexicamérica: La frontera de los ilegales. La literatura y la frontera», art. cit.

32. Citemos solamente el caso del escritor boliviano, afincado en EEUU, Edmundo Paz Soldán y de su última novela, Norte (2011), a la cual dedicamos otro trabajo. Se aprecia un diálogo entre esta novela y Trabajos del reino de Yuri Herrera. Ambos autores se conocen, se leen y se comentan mutuamente.

33. M. S. Tabuenca, «Reflexiones sobre la literatura de la frontera», Puentelibre: Revista de Cultura, vol. 4, 1995, p. 9.

\section{RESÚMENES}

La frontera entre México y Estados Unidos es el nuevo sitio de construcción de un imaginario identitario, inscribiéndose en la trayectoria de autognosis de las letras mexicanas. Sin embargo, por su carácter multifacético, maleable y mutante, la frontera sugiere otras formas de plantear la identidad mexicana, dejando atrás las monolíticas formas del pasado. Este trabajo se centra en las obras de David Toscana (El ejército iluminado, 2006) y de Yuri Herrera (Trabajos del reino, 2004, y Señales que precederán al fin del mundo, 2010). En estas novelas se hace operativa la problemática de la mirada, o más bien del cruce de miradas, que se focaliza en este espacio geográfico y cultural. La resultante es una visión que busca rectificar, a través de recursos múltiples, viejos agravios históricos, ciertos estereotipos o, sencillamente, sugerir que la realidad de la frontera permanece inasible, ambigua o equívoca. De tal forma que hasta el mismo concepto de frontera oscila entre ruptura y continuidad, en el sentido amplio de los términos: entre categorías conceptuales u ontológicas hasta categorías socioculturales ancladas en un referente preciso.

La frontière entre le Mexique et les États-Unis est le nouveau lieu de construction d'un imaginaire identitaire, qui s'inscrit dans la démarche d'auto-gnose des lettres mexicaines. Cependant, par son caractère multiple, malléable et mutant, la frontière suggère d'autres façons de poser le problème de l'identité mexicaine, loin des formes monolithiques du passé. Ce travail s'appuie sur les ouvrages de David Toscana (El ejército iluminado, 2006) et de Yuri Herrera (Trabajos del reino, 2004, et Señales que precederán al fin del mundo, 2010). Ces romans mettent en œuvre la problématique du regard, ou plutôt des regards croisés, focalisée sur cet espace géographique et culturel. Le résultat est une vision qui tente de rectifier, de multiples façons, certains affronts 
inscrits dans l'histoire ainsi que différents stéréotypes, suggérant également que la réalité de la frontière demeure hors de portée, ambiguë ou équivoque. Si bien que le concept même de frontière oscille entre la rupture et la continuité, ces deux termes étant pris dans un sens large : entre catégories conceptuelles et ontologiques ou entre catégories socioculturelles ancrées dans un référent concret.

The US-Mexican border is the place where a new imaginary identity is under construction in the wake of a self-gnosis process in the field of Mexican letters. Yet, the plentiful, malleable and transitory nature of the frontier brings about new ways of tackling the issue of Mexican identity, far from the monolithic forms of the past. This article is based on the works of David Toscana ( $E l$ ejército iluminado, 2006) and Yuri Herrera (Trabajos del reino, 2004, and Señales que precederán al fin del mundo, 2010). These novels highlight the complex issue of how glances are exchanged across the border, focusing on this geographical and cultural space. The result is a vision attempting in many ways to rectify some affronts written down in history as well as some stereotypes, also suggesting that the reality of the border remains out of reach, ambiguous or equivocal. Thus, the very concept of border keeps shifting between rupture and continuity, both terms being taken in a broad sense: between conceptual and ontological, or between socio-cultural categories rooted in a concrete set of references.

ÍNDICE

Keywords: Mexican literature, border, novel, David Toscana, Yuri Herrera

Palabras claves: literatura mexicana, frontera, novela, David Toscana, Yuri Herrera

Mots-clés: littérature mexicaine, frontière, roman, David Toscana, Yuri Herrera

\section{AUTOR}

\section{MARGARITA REMÓN-RAILLARD}

Université Grenoble Alpes, ILCEA 